\title{
PSIKOLOGI CYBER MEDIA SENI KOMUNIKASI PROPAGANDA MENGGUNAKAN MEDIA SOSIAL DALAM KAITANNYA DENGAN ISU SARA DI INDONESIA
}

\author{
Oleh: \\ Fajar Dwi Putra \\ Fakultas Sastra, Budaya dan Komunikasi Universitas Ahmad Dahlan Yogyakarta \\ Program Studi Ilmu Komunikasi \\ E-mail : jokadesanta@yahoo.com/dwiputra@fsbk.uad.ac.id
}

\begin{abstract}
ABSTRAK
Pembentukan karakter dan kepribadian seseorang ditentukan ketika seseorang tersebut bersosialisasi dengan lingkungan sekitarnya. Baik itu lingkungan fisik yang diperoleh dengan pergaulan secara langsung, melalui buku atau media cetak maupun melalui media-media elektronik seperti televisi, radio bahkan internet. Kehadiran media sosial, seperti Facebook, Twitter, Blog, Path, BBM, dan sebagainya, membawa perubahan yang sangat radikal dalam berkomunikasi. Apalagi media sosial tersebut dapat dilihat melalui telepon genggam atau telepon seluler (ponsel) yang semua orang bisa mengaksesnya kapan saja. Melalui media sosial pula kita dapat melakukan interaksi sosial dalam berbagai macam bentuk pertukaran, kolaborasi dan saling mengenal satu sama lain dalam jenis gambar/foto dan audio visual.
\end{abstract}

Kata kunci : Komunikasi Persepsi

\begin{abstract}
The formation of a person's character and personality is determined when the person is socializing with the environment. Whether it is the physical environment obtained by association directly, through books or print media or through electronic media such as television, radio and even the internet. The presence of social media, such as Facebook, Twitter, Blogs, Paths, BBM, and so on, bring a very radical change in communicating. Moreover, social media can be viewed through a mobile phone or cellular phone that everyone can access it any time. Through social media we can also interact socially in various forms of exchange, collaboration and getting know each other by using image or photo and audio visual.
\end{abstract}

Keywords: perception communication.

\section{A. PENDAHULUAN}

Kurangnya pengetahuan dan keterampilan dalam memilah-milah dan memastikan keabsahan berita, menyebabkan masyarakat pengguna media sosial rentan terhadap isu provokatif, berita palsu, atau informasi yang tidak akurat. Sehingga tidak sedikit yang kemudian langsung mempercayai, menanggapi, dan membagikan informasi yang tidak akurat tersebut kepada orang lain. Selain permasalahan seputar rumah ibadat, penyiaran agama, penodaan agama, secara nyata, sadar atau tidak masyarakat disuguhi berbagai paham keagamaan yang keluar dari arus pemahaman "mainstream" yang akan berpengaruh terhadap wajah kerukunan umat beragama di Indonesia. Pada titik tertentu kondisi ini tidak menimbulkan masalah, tetapi manakala ekspresi keagamaanya berbenturan dengan sistem 
dan paham keagamaan "mainstream" secara tajam maka akan menimbulkan berbagai permasalahan.

Alasan utama, dengan mengatasnamakan kebebasan berpikir dan berpendapat, beberapa pengguna media sosial dengan bebas mengutarakan pendapatnya berdasarkan informasi yang belum pasti kebenarannya. Maka tidaklah heran jika banyak terjadi kasus perdebatan personal atau antar kelompok yang dipicu oleh suatu postingan kata-kata seseorang (status/tweet) atau berita, gambar dan video dari situs yang tidak jelas sumbernya. Kekerasan sosial yang memanas seperti yang terjadi di Tanjung Balai beberapa waktu lalu adalah fenomena kekerasan sosial yang secara visual "layak jual". Media sosial membungkus kekerasan visual yang memanas itu menjadi sebuah komoditas yang laris manis untuk dikomodifikasikan. Bentuk konkret komodifikasi kekerasan visual yang disuguhkan media sosial secara detail dan vulgar adalah melalui kotak atau kolom komentar.

Penyebab terjadinya kondisi di atas, karena masyarakat mengalami desensitifikasi atau menurunnya rasa sensitif terhadap orang lain. Perang komentar atau opini di media sosial yang memperdebatkan isu Agama seakan menjadi akumulasi emosi dari individu terhadap kelompok yang saling berlawanan. Kondisi itu terjadi karena komunikasi dalam perang komentar berjalan secara tidak langsung, antara pihak yang berseteru tidak berhadapan langsung secara fisik. Faktor lainnya adalah adanya deindividualisasi, yakni menurunnya kesadaran diri. Pelaku perang komentar merasa dirinya tidak dikenali oleh pihak lawan dan merasa nyaman dalam kelompoknya. Selain itu, komentar yang menghina, merusak orang atau pihak lain dianggap sebuah hal yang biasa. Semakin kontroversial status yang ditulis, semakin panas ujaran kebencian yang dibagikan. Tidak sekedar memicu adrenalin masing-masing pihak yang merasa pendapatnya paling benar. Terungkap jika kebiasaan perang urat syaraf di media sosial dapat mengganggu kesehatan mental. (www.kompasiana.com, diakses pada tanggal 5 Oktober 2017)

Dalam penggunaan media sosial, tentu seseorang memiliki berbagai motivasi diantaranya untuk sekedar berkomunikasi dengan orang lain, untuk mencari tahu perkembangan dunia dan untuk berbagi informasi. Salah satu yang menjadi trend saat ini adalah penggunaan media sosial untuk menyebarkan konten SARA dengan maksud mempropaganda golongan tertentu untuk menciptakan berbagai bentuk diskriminasi. Diskriminasi merupakan suatu kejadian yang biasa dijumpai dalam masyarakat manusia, ini disebabkan karena kecenderungan manusia untuk membeda-bedakan yang lain. Ketika seseorang diperlakukan secara tidak adil karena karakteristik suku, antargolongan, kelamin, ras, agama dan kepercayaan, aliran politik, kondisi fisik atau karateristik lain yang diduga merupakan dasar dari tindakan diskriminasi.

Diskriminasi langsung, terjadi saat hukum, peraturan atau kebijakan jelas-jelas menyebutkan karakteristik tertentu, seperti jenis kelamin, ras, dan sebagainya, dan menghambat adanya peluang yang sama. Diskriminasi tidak langsung, terjadi saat peraturan yang bersifat netral menjadi diskriminatif saat diterapkan di lapangan. SARA akhir-akhir ini muncul sebagai masalah yang dianggap menjadi salah satu sebab terjadinya berbagai gejolak sosial di Indonesia. Perkelahian antara suku Madura dan suku Dayak di Kalimantan Barat, perkelahian antara suku Makasar dan penduduk asli Timor yang kemudian berkembang menjadi pergesekan antaragama Nasrani dan Islam, merupakan 
contoh peristiwa SARA (suku, agama, ras, antargolongan) di negara kita. Indonesia terdiri dari pulau-pulau dan suku bangsa, maka masalah SARA merupakan hal biasa. Tapi ada beberapa hal menarik untuk dicermati dalam masalah SARA. Pertama, hubungan antara suku pribumi dan nonpribumi atau etnis Cina sampai saat ini belum dapat dipecahkan, dan tetap menjadi pemicu potensial timbulnya konflik sosial. (Zuly, 2011:12)

SARA muncul kembali sebagai faktor pendorong timbulnya "nasionalisme daerah", berupa upaya memisahkan suatu wilayah dari wilayah Republik Indonesia, meskipun masalah ini secara historis seharusnya sudah selesai ketika bangsa ini memproklamasikan Sumpah Pemuda 1928. Kuat dugaan ada gejala bergesernya sebab pemicu timbulnya gejolak sosial dari masalah SARA bergeser ke masalah yang bersifat struktural. SARA, khususnya agama, sering terlihat menjadi pemicu. Namun kita perlu bersikap hati-hati sebelum mengambil kesimpulan bahwa agama "adalah pemicu utama" pecahnya suatu konflik sosial. Faktor agama dari SARA hanya menjadi alternatif kedua suatu masalah yang lebih besar. SARA tak akan mampu memicu terjadinya suatu ketegangan apabila tak terkait dengan faktor struktural yang ada dalam masyarakat. Gejala menarik yang terjadi di Indonesia adalah adanya satu birokrasi yang merupakan bagian suatu organisasi sosial politik atau orsospol. Dekadensi moral birokrasi itu dapat memancing ketegangan sosial yang manifestasinya adalah pada tindakan SARA. (Sam, 2006: 34)

Untuk menghembuskan isu SARA saat ini bisa diambilalih oleh media sosial atau jejaring sosial. Pertanyaanya, mengapa media sosial sedemikian dahsyat dalam menyebarkan pesan-pesannya? Pertama, masyarakat sedang euforia untuk tak menyebut kemaruk media sosial. Media itu sedang digandrungi masyarakat dunia. Tak ada warga kota yang tidak terpengaruh oleh media sosial. Bahkan semua media massa cetak dan elektronik sekarang harus memanfaatkan media sosial itu untuk menyebarkan pesanpesannya. Dimanapun tempatnya, masyarakat memanfaatkan media sosial. Itu bukti betapa hebatnya pengaruh media sosial. Bahkan Indonesia menduduki ranking ke-4 pemakai facebook (43 juta pengguna) setelah Amerika, India, dan Brazil. (sumber: www.google.com diakses 7 Oktober 2017) Kedua, media sosial mampu menyebarkan pesan secara revolusioner. Pesan yang disebarkan lewat media sosial sedemikian dahsyatnya memengaruhi sikap dan perilaku masyarakat. Ketiga, kepercayaan masyarakat pada media sosial melebihi kenyataan sebenarnya. Ini bisa dilihat karena sedemikian kuatnya kepercayaan manusia pada media sosial, meskipun kenyataannya belum tentu seperti itu.

Efek Psikologis yang segera menyusul secara langsung adalah: Gangguan kepribadian berupa emosi yang sebentar-sebentar meledak di saat online mengamuk karena mudah tersinggung (Online Intermittent Explosive Disorder/OIED) dan Internet Asperger's Syndrome atau hilangnya semua aturan sosial dan empati pada diri seseorang, disebabkan tanpa alasan selain hanya secara kebetulan berhadapan dengan sebuah benda mati (berkomunikasi via papan tombol dan monitor pada suatu waktu.) (Robert, 2003: 37)

Di Indonesia perang media sosial juga marak terjadi, isu SARA dijadikan sasaran oleh oknum-oknum yang tak bertanggungjawab melalui media sosial, sehingga memecah belah kesatuan dan persatuan bangsa Indonesia. Satu hal yang harus diperhatikan dalam menggunakan media sosial adalah tidak adanya redaksional, sehingga pesan yang 
disampaikan cenderung tidak terkontrol. Efek berikutnya yang muncul ialah perbedaan persepsi.

Berikut data yang penulis ambil dari www.google.com yang diakses pada tanggal 05 Oktober 2017 tentang ujaran kebencian yang berkaitan dengan SARA.

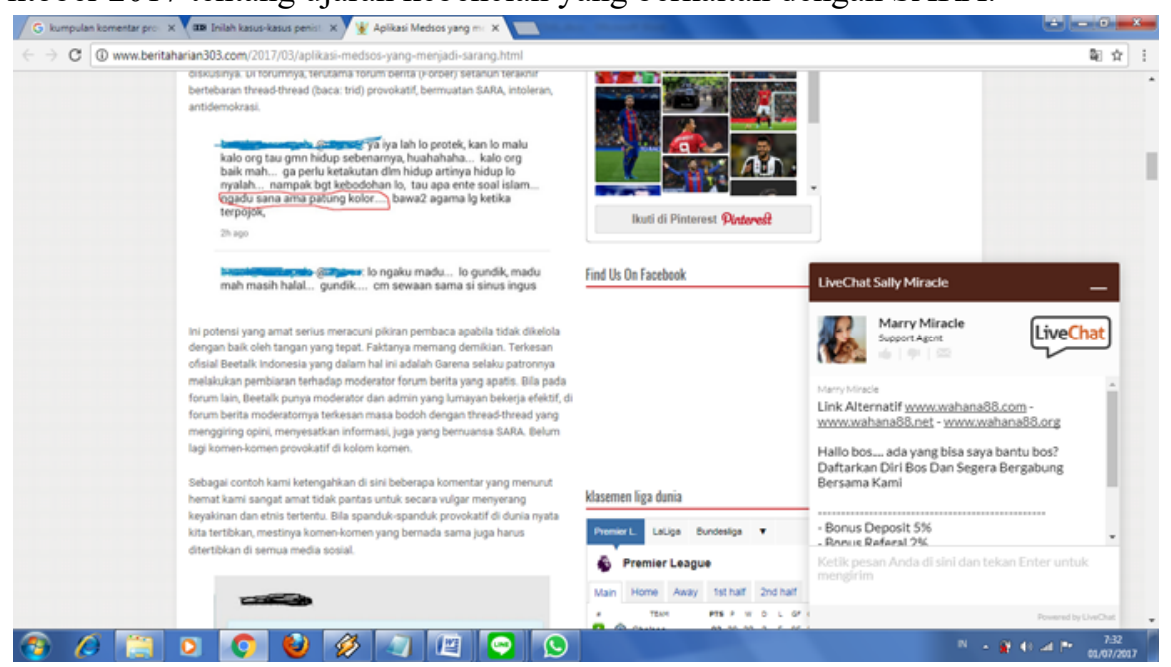

Gambar 1.

Dampak kasus Ahok

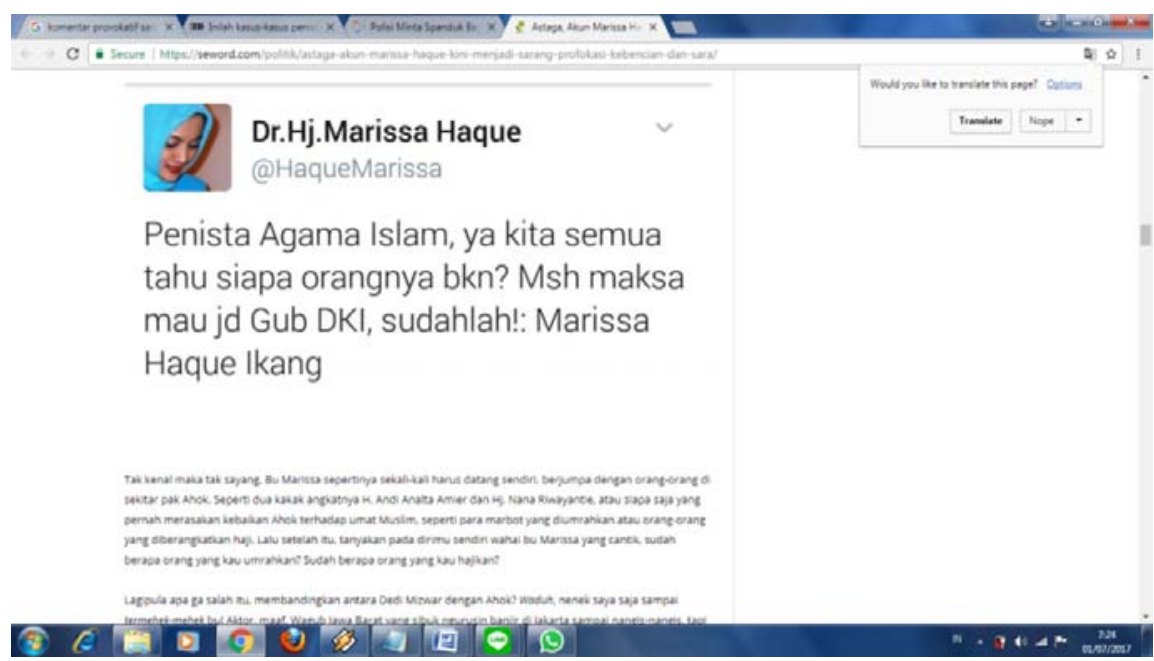

Gambar 2.

Artis yang berpendidikan pun mengunggah status bernada SARA 


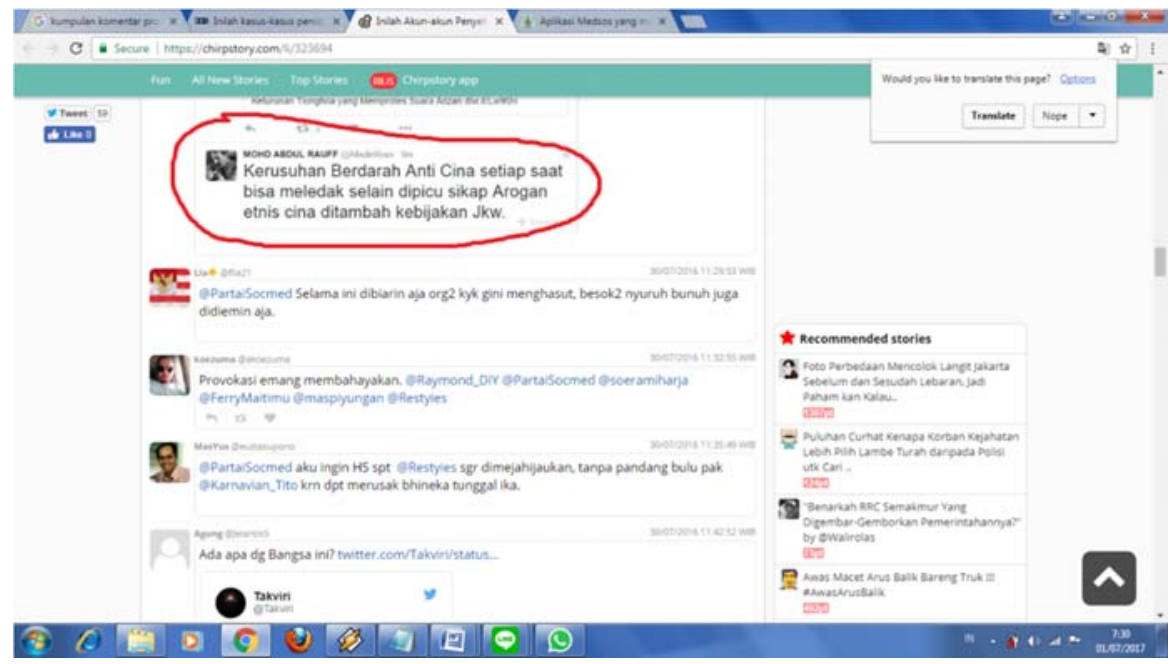

Gambar 3.

Netizen mengunggah status SARA yang dikaitkan dengan pemerintahan

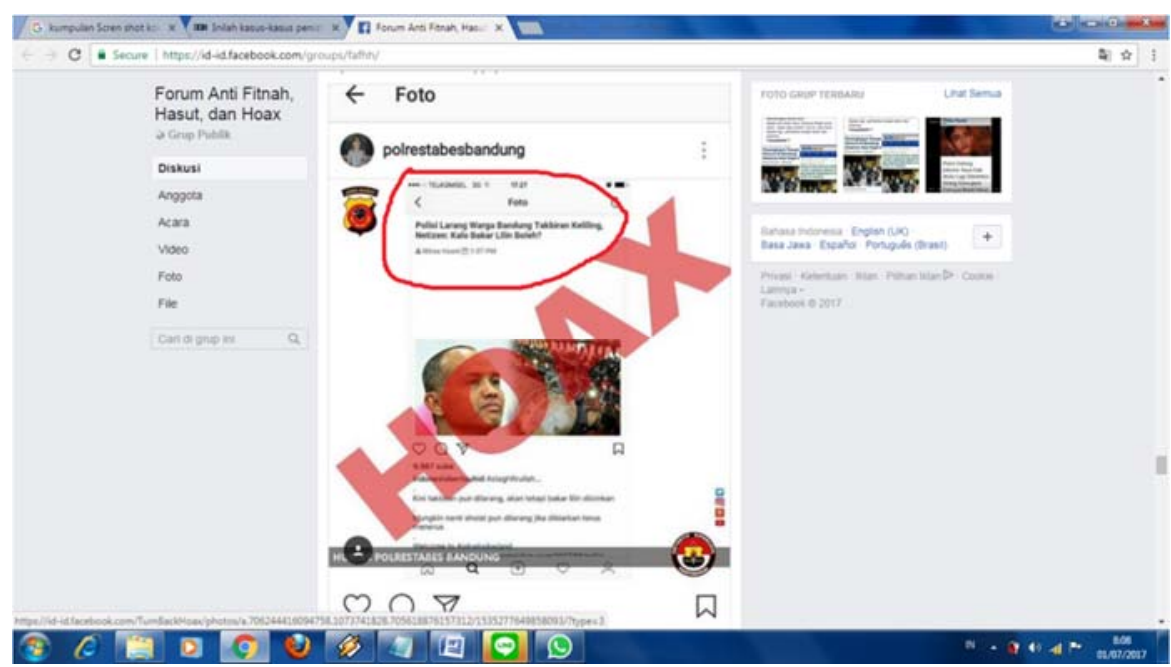

Gambar 4.

Netizen yang mengunggah status ujaran kebencian bernada SARA 


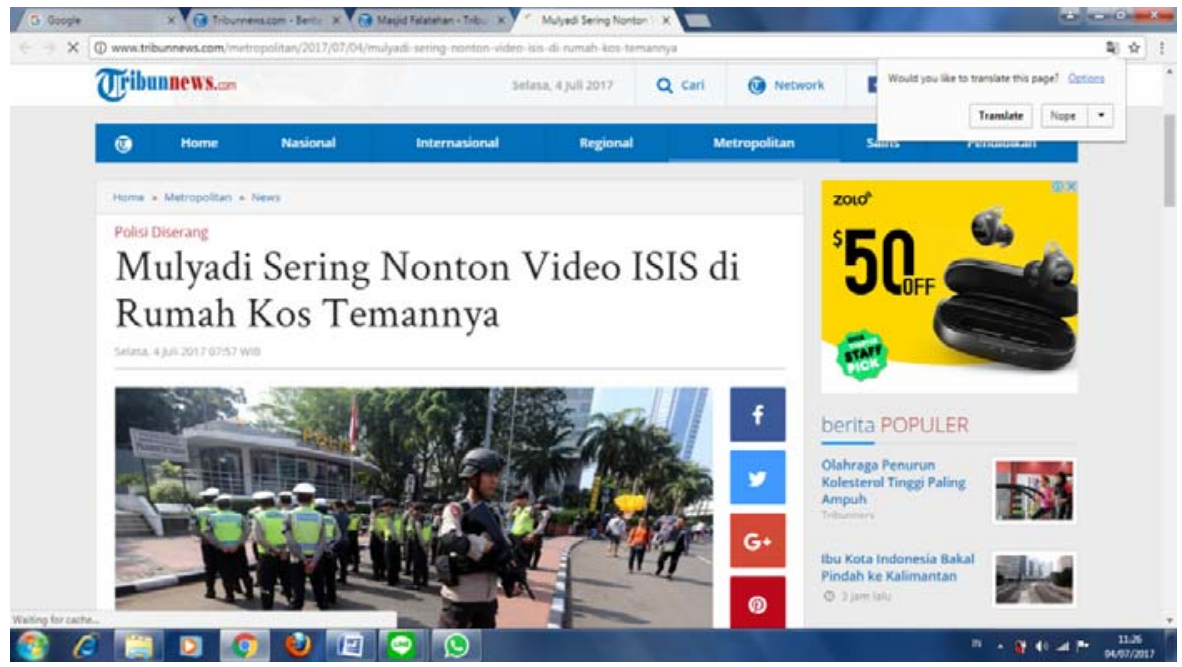

Gambar

Kasus Falatehan

http://www.tribunnews.com/metropolitan/2017/07/04/mulyadi-sering-nonton-video-isisdi-rumah-kos-temannya

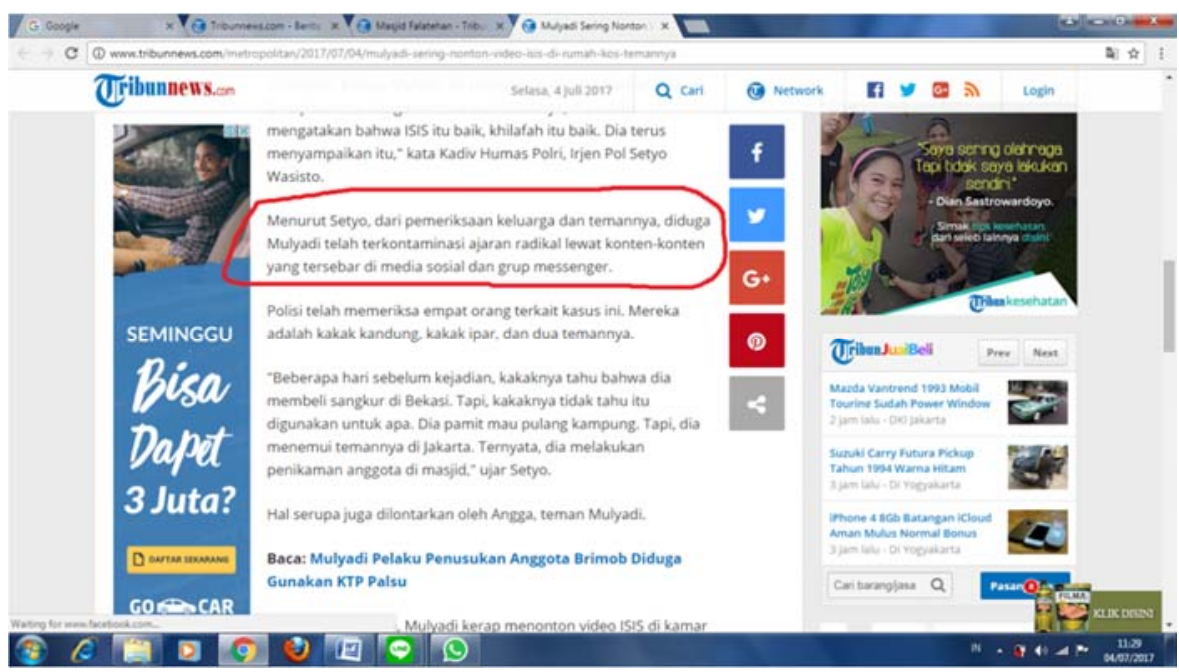

Gambar 6

Kasus Falatehan

http://www.tribunnews.com/metropolitan/2017/07/04/mulyadi-sering-nonton-video-isisdi-rumah-kos-temannya

Di Indonesia jumlah pengguna media sosial sudah begitu banyak, berikut adalah data tentang pengguna internet yang penulis peroleh dari http://www.apjii.com/ APJII (Asosiasi Pengguna Jasa Internet Indonesia) 2016 yang diakses pada tanggal 2 Oktober 2017 


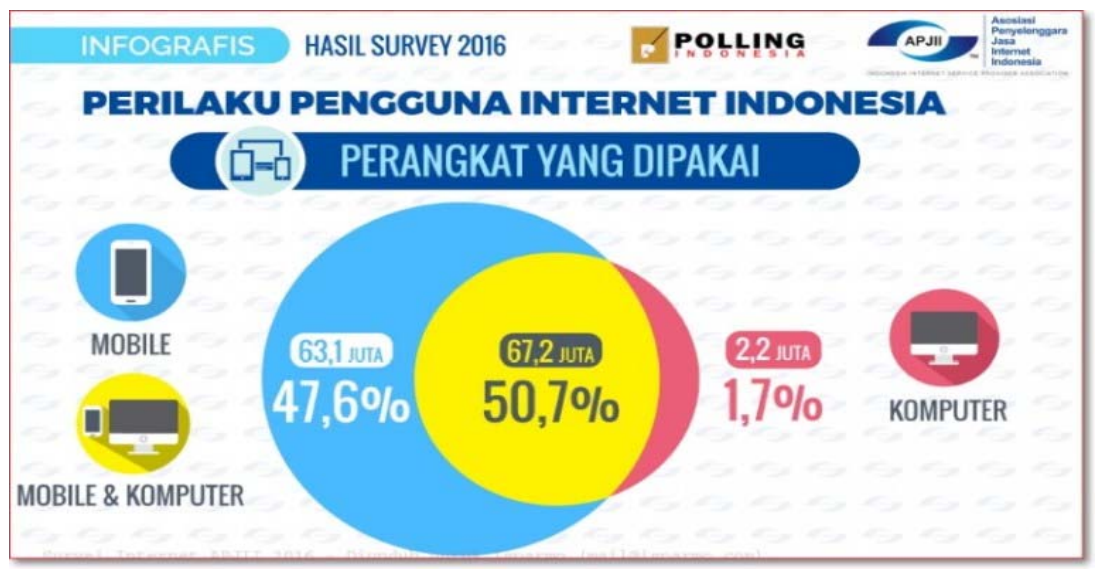

Gambar 7

Berdasarkan Perangkat yang dipakai

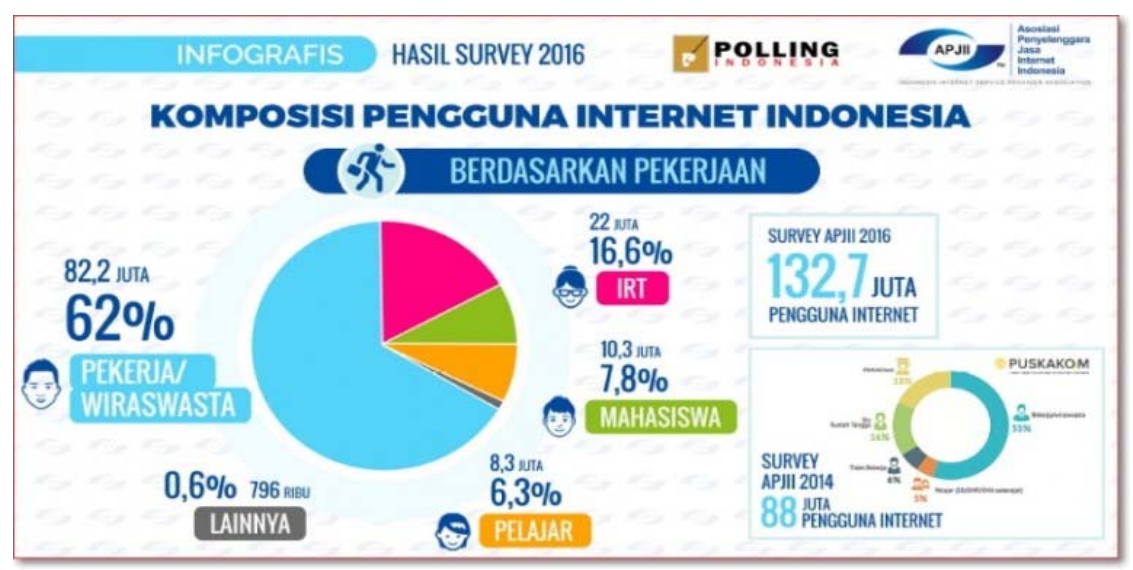

Gambar 8

Berdasarkan Pekerjaan

\section{INFOGRAFIS HASIL SURVEY 2016 \\ PERILAKU PENGGUNA INTERNET INDONESIA}

CPOLLING APII

【. KONTEN KOMERSIAL YANG SERING DI KUNUUNGI $\square$ KONTENMEDIA SOSIAL YANG SERINGDI KUNUNGI

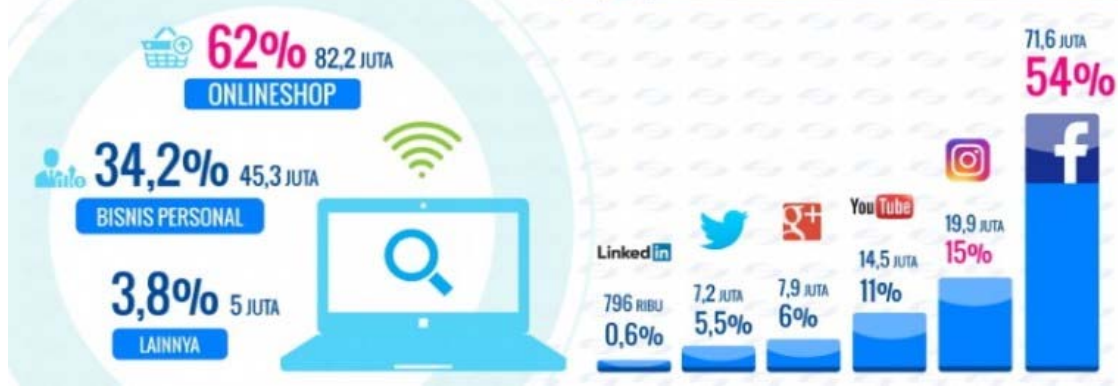

Gambar 9

Berdasarkan Perilaku 


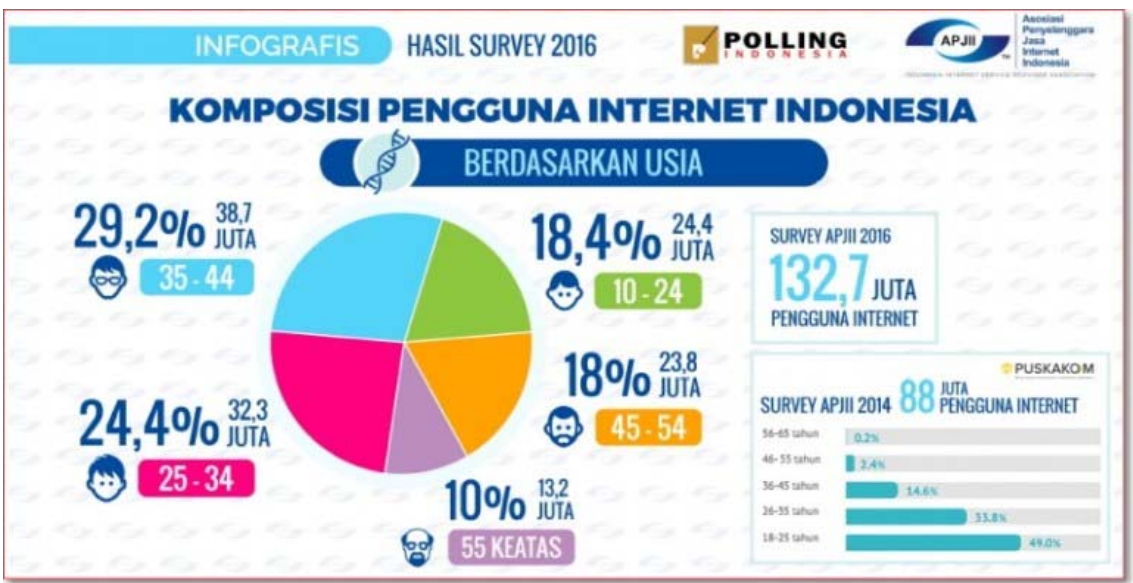

Gambar 10

Berdasarkan Usia

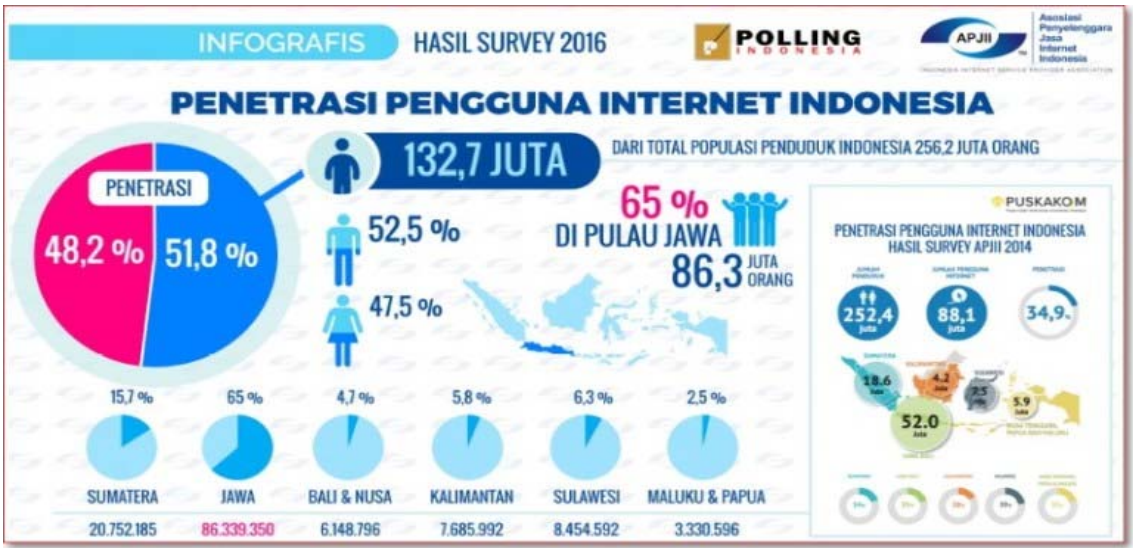

Gambar 11

Penetrasi Penggunaan internet di Indonesia

Penulis menjadikan paparan data, kasus dan kondisi di atas sebagai dasar alasan untuk melakukan sebuah penelitian. Sehingga, penulis berpendapat perlu adanya penggabungan antara teori Psikologi sains dengan teori Komunikasi massa menjadi teori Psikologi Cyber Media untuk membuat sebuah "redaksi" dengan cara memberikan pemahaman aspek-aspek Psikologi yang dapat dijadikan rujukan oleh Netizen dalam menggunakan media sosial. Menurut pandangan penulis, dengan melakukan penelitian ini maka konteks relevansi dalam pengembangan keilmuan ada pada ranah Psikologi yang nantinya akan mengembangkan teori-teori Psikologi murni atau sains dengan teori Komunikasi media atau Komunikasi massa. 


\section{B. TINJAUAN PUSTAKA}

1. Media Sosial Sebagai Sebuah Komunikasi Massa

Joseph A. Devito (2011: 43-45) mengatakan media sosial dan komunikasi massa adalah suatu proses di mana komunikator menggunakan media untuk menyebarkan pesanpesan secara luas, dan secara terus menerus menciptakan makna-makna yang diharapkan dapat mempengaruhi khalayak yang besar dan berbeda-beda dengan berbagai cara.

Menurut B.R Hergenhahn Matthew H. Olson (2010:175-177) beberapa ciri lingkungan media baru adalah:

1. Teknologi yang dahulu berbeda dan terpisah seperti percetakan dan penyiaran sekarang bergabung menjadi satu kesatuan utuh.

2. Kita sedang bergeser dari kelangkaan media menuju media yang berlimpah.

3. Anonim, (tidak saling mengenal) baik komunikator maupun komunikan dalam komunikasi massa tidak mengenal satu sama lain.

2. Jenis Komunikasi

Menurut Joseph A. Devito (2011:125-134) jenis komunikasi dibedakan menjadi beberapa pandangan, diantaranya adalah:

a. Komunikasi Lisan: Yang dimaksud dengan komunikasi lisan adalah komunikasi yang terjadi secara langsung dan tidak dibatasi oleh jarak, yang artinya komunikasi bentuk ini dilakukan antara kedua belah pihak secara bertatap muka.

b. Komunikasi Tertulis: Komunikasi tertulis adalah salah satu bentuk komunikasi yang berupa tulisan, komunikasi ini biasanya berupa surat dan dipergunakan untuk menyampaikan suatu berita yang singkat, jelas, dan dipandang perlu untuk ditulis dengan maksud tertentu.

3. Komunikasi Menurut Perilakunya

Komunikasi dipelajari oleh manusia melalui proses kehidupannya, melalui belajar, bersosial dan lain sebagainya yang tentunya akan secara otomatis dipengaruhi oleh perilaku dan posisi seseorang didalam masyarakat, berikut merupakan jenis komunikasi menurut perilakunya:

a. Komunikasi Formal: Komunikasi formal biasanya terjadi dalam suatu organisasi, komunikasi seperti ini biasanya sudah mempunyai aturan dan tata caranya sendiri menurut rules dari organisasi atau perusahaanya.

b. Komunikasi Informal: Komunikasi informal terjadi dalam suatu oraganisasi yang tidak ditentukan dalam struktur organisasi dan tidak dapat pengakuan resmi dan juga tidak berpengaruh terhadap kepentingan organisasi yang bersangkutan, misalnya adalah obrolan antar teman, desa-desus dan lain sebagainya.

c. Komunikasi Nonformal: Komunikasi nonformal adalah komunikasi yang terjadi antara bersifat formal dan informal, yaitu komunikasi yang bertujuan dengan pelaksanaan tugas pekerjaan organisasi. 
4. Komunikasi Yang Didasarkan Menurut Aliran Informasi Dapat Dibedakan Sebagai Berikut :

a. Komunikasi satu arah, yaitu merupakan komunikasi yang berlangsung dari satu pihak saja.

b. Komunikasi dua arah, yaitu komunikasi yang bersifat timbal balik, dalam hal ini komunikasi diberi kesempatan untuk memberikan respons atau feedback kepada komunikatornya.

c. Komunikasi ke atas yaitu merupakan komunikasi yang terjadi dari bawahan kepada atasan.

d. Komunikasi ke bawah, yaitu merupakan komunikasi yang terjadi dari atasan kepada bawahan.

e. Komunikasi kesamping, yaitu merupakan komunikasi yang terjadi diantara orang yang memiliki kedudukan sejajar. Dengan demikian arah informasi tersebut akan dianut sebagai bentuk interaksi komunikasinya.

5. Jenis Komunikasi Menurut Jaringan Kerja.

Dalam konteks media sosial, jenis komunikasi ini biasanya terjadi melalui groupgroup sosial media yang dibentuk berdasarkan lingkungan pekerjaan, komunitas dan kesepahaman, diantaranya adalah:

a. Komunikasi jaringan kerja rantai: Komunikasi terjadi menurut saluran hirarki organisasi dengan jaringan komando sehingga mengikuti pola komunikasi formal.

b. Komunikasi jaringan kerja lingkaran: Komunikasi terjadi melalui saluran komunikasi yang berbentuk seperti lingkaran.

c. Komunikasi jaringan bintang: Komunikasi yang terjadi melalui satu sentral dan saluranya yang dilalui lebih pendek.

6. Jenis Komunikasi Menurut Peranan Individu.

a. Komunikasi antara individu dengan individu yang lain.

b. Komunikasi antara individu dengan lingkungan yang lebih luas.

c. Komunikasi antara individu dengan dua kelompok atau lebih.

7. Jenis Komunikasi Menurut Jumlah Pelaku Dalam Komunikasi.

a. Komunikasi Perseorangan: Komunikasi yang terjadi secara perseorangan atau individual antara pribadi dengan pribadi tentang permasalahan yang bersifat pribadi juga.

b. Komunikasi Kelompok: Komunikasi yang berlangsung dalam suatu kelompok atau group tentang masalah-masalah yang menyangkut kepentingan banyak orang dalam kelompok.

8. Seni Berkomunikasi

Menurut Morisan (2010: 150-152) ada tiga karakter untuk membangun seni berpendapat atau seni berkomunikasi, diantaranya adalah:

100 Fajar Dwi Putra 
a. Menumbuhkan Seni Mendengar

Dalam kaligrafi Tiongkok, kata komunikasi diartikan sebagai seni mendengar. Ada unsur kata kuping untuk mendengar, mata untuk melihat, hati yang mempedulikan. Itu semua merupakan kesatuan yang sempurna dan tak terpisahkan. Orang yang mampu mendengar dengan baik akan jadi seperti raja yang mampu mengendalikan situasi. Kita belajar ketika mendengar. Kita lebih disukai dan menjadi lebih bijaksana bukan ketika berbicara, tapi ketika kita mendengarkan.

b. Mengelola Penguasaan Diri

Perkataan dapat membangun, tetapi juga dapat meruntuhkan. Dengan lidah kita dapat memuji Tuhan, namun juga bisa mengutuk orang. Penguasaan diri juga berbicara tentang waktu, tempat, dan dalam situasi yang tepat kita dapat berkomunikasi.

c. Membangun Sikap Empati

Empati adalah perhatian dan kasih yang diwujudkan melalui tindakan. Empati dalam komunikasi berarti kata-kata yang disertai tindakan selaras. Komunikasi yang bijak adalah komunikasi yang dapat menyimak kebutuhan orang lain, bukan sekadar kepentingan pribadi dan kepuasan berbicara.

\section{Sara}

Menurut Zuly Qodir (2011:75-77), pemahaman SARA berbagai pandangan dan tindakan yang didasarkan pada sentimen identitas yang menyangkut keturunan, agama, kebangsaan atau kesukuan dan golongan. Setiap tindakan yang melibatkan kekerasan, diskriminasi dan pelecehan yang didasarkan pada identitas diri dan golongan dapat dikatakan sebagai tidakan SARA. Tindakan ini mengebiri dan melecehkan kemerdekaan dan segala hak-hak dasar yang melekat pada manusia. Dalam pengertian lain SARA dapat di sebut diskriminasi yang merujuk kepada pelayanan yang tidak adil terhadap individu tertentu, di mana layanan ini dibuat berdasarkan karakteristik yang diwakili oleh individu tersebut. SARA dapat digolongkan dalam tiga katagori, yaitu:

d. Kategori pertama yaitu Individual: merupakan tindakan SARA yang dilakukan oleh individu maupun kelompok. Termasuk di dalam katagori ini adalah tindakan maupun pernyataan yang bersifat menyerang, mengintimidasi, melecehkan dan menghina identitas diri maupun golongan.

e. Kategori kedua yaitu Institusional: merupakan tindakan SARA yang dilakukan oleh suatu institusi, termasuk negara, baik secara langsung maupun tidak langsung, sengaja atau tidak sengaja telah membuat peraturan diskriminatif dalam struktur organisasi maupun kebijakannya.

f. Kategori ke tiga yaitu Kultural: merupakan penyebaran mitos, tradisi dan ide-ide diskriminatif melalui struktur budaya masyarakat.

\section{METODE PENELITIAN}

Pendekatan yang digunakan dalam penelitian ini adalah pendekatan fenomenologi. Fenomenologi berusaha untuk mengungkap dan mempelajari serta memahami suatu fenomena beserta konteksnya yang khas dan unik yang dialami oleh individu atau suatu 
kelompok hingga tataran "keyakinan". Dengan demikian dalam mempelajari dan memahaminya, haruslah berdasarkan sudut pandang dan paradigma.

Sesuai dengan jenis, ciri-ciri dan sumbernya, maka pengumpulan data dalam seluruh aktivitas penelitian ini dilakukan melalui tehnik sebagai berikut:

1. Dokumentasi yang digunakan dalam rangka mencari dan mengumpulkan data berupa dokumen atau data tertulis lain yang menginformasikan keadaan riil sekarang. Pengumpulan data melalui dokumentasi ini merupakan metode pengumpulan data dengan cara mencari data mengenai hal-hal atau variabel berupa catatan, surat surat, dokumen dokumen lainnya.

2. Analisis data adalah suatu proses pengklasifikasian, pengkategorian, penyusunan, dan elaborasi, sehingga data yang telah terkumpul dapat diberikan untuk menjawab masalah penelitian yang telah dipaparkan.

Proses analisis mengalir dari tahap awal hingga tahap penarikan kesimpulan hasil studi. Proses analisa kualitatif tersebut dapat dijelaskan kedalam tingkah laku sebagai berikut:

1. Reduksi data (data reduction)

Reduksi data adalah proses pemilihan, pemusatan, perhatian pada penyederhanaan, abstraksi, dan tranformasi data kasar yang diperoleh selama melakukan kajian analisis sumber data. Dengan data ini, peneliti akan menyeleksi data dari hasil studi dokumentasi dengan cara memfokuskan pada data yang lebih menarik, penting, berguna, dan baru. Data yang dirasa tidak penting disingkirkan. Berdasarkan pertimbangan tersebut, maka data-data tersebut selanjutnya dikelompokkan menjadi berbagai kategori yang ditetapkan sebagai fokus penelitian.

2. Penyajian Data (data display)

Setelah data direduksi, maka langkah selanjutnya adalah mendisplaykan data. Display data merupakan proses mendiskripsikan kumpulan informasi secara sistematis dalam bentuk susunan yang jelas untuk membantu peneliti menganalisis hasil penelitian. Untuk memudahkan penyajian data ini peneliti membuat catatan dalam bentuk teks naratif untuk memudahkan penguasaan informasi atau data yang dimaksud.

3. Penarikan kesimpulan dan verifikasi ( conclution drawing and verification)

Penarikan kesimpulan dan verifikasi merupakan kegiatan interprestasi dengan maksud untuk menemukan makna dari data yang telah disajikan, misalnya dengan menghubungkan antara data satu dengan yang lain.

Kesimpulan data dilakukan secara sementara, kemudian diverifikasikan dengan cara mencari data yang lebih mendalam dengan mempelajari kembali hasil data yang telah terkumpul. Pengecekan informasi atau data dapat dilakukan oleh setiap peneliti sesuai pengumpulan data, ditempuh dengan cara menganalisis subjek penelitian yaitu media sosial.

Komponen komponen analisis data (yang mencakup reduksi penyajian data dan penarikan kesimpulan) secara interaktif saling berhubungan selama dan sesudah pengumpulan data. Atas dasar tersebut, karakter analisis dan kualitatif disebut pula sebagai model interaktif. 
Mengingat sifat deskriptif dari penelitian ini, maka peneliti dalam menyajikan data yang di temukan dengan metode deskriptif analitik, cara berpikir induktif sehingga hasil temuan dapat disajikan secara lebih akurat dan dideskripsikan secara lebih baik.

\section{PEMBAHASAN}

\section{Alat Propaganda}

Propaganda merupakan sarana yang terselubung dalam kajian Jurnalistik, ia hadir dalam dimensi yang berbeda, masuk melalui celah-celah yang sempit, namun hasilnya dapat memberikan effek besar pada negara dan dunia. Media massa merupakan satu dari alat yang harusnya nampak secara fisik, namun dengan adanya propaganda media saat ini menjadi samar atau jenisnya menjadi grey alias abu-abu, antara membela rakyat atau menjadi oportunis.

Propaganda sebagai sebuah ilmu, ia akan membuahkan hasil positif jika melekat pada kepribadian yang baik, begitu sebaliknya, jika melekat pada pribadi yang kurang baik maka akan menjadi kurang baik juga. Jadi, propaganda hanya sebuah alat, baik atau buruknya tergantung dari siapa pelaku yang ada di belakangnya.

Bisa jadi, komunikasi dalam media sosial ini digunakan oleh orang yang berambisi kekuasaan tanpa mengindahkan apakah kegiatan itu merugikan orang banyak atau tidak, benar atau tidak, semuanya dipikir belakangan, yang penting target tujuan tertentu tercapai dengan baik sesuai dengan rencana. Memainkan emosi masyarakat melalui media sosial memang sangat mudah, sebab media sosial adalah media yang tidak ada redaksinya, membuat semua orang dapat mengakses.

\section{Seni Komunikasi Propaganda}

Pada awalnya manusia terpengaruh oleh sistem pemikiran pra-konsepsi dan nilainilai yang tertanam di dalam benaknya semenjak anak-anak akibat pengaruh lingkungan sosialnya. Pra konsepsi dan nilai-nilai tersembunyi di relung-relung tak sadar dalam dirinya. Manusia menerapkannya pada objek yang dilihatnya dan sering sekali menganggapnya sebagai sebuah ketidaksadaran.

Ini disebabkan pandangan dunia manusia dipengaruhi oleh tiga faktor, diantaranya adalah:

a. Kecenderungan Personal

b. Pandangan Kultural

c. Kedudukan Sosial

Kalau kita bicara personal dalam konteks propaganda, maka konteks itu tidak pernah akan lepas dari siapa yang ada di belakang layar. Kecenderungan personal menjadi latar utama dalam menyikapi akan seperti apa dampak ke depannya. Seni propaganda ini adalah sebuah metode berkomunikasi dengan mempertimbangkan effek Psikologi secara mendalam, sehingga akan terwujud sebuah komunikasi yang baik tanpa ada yang dirugikan khususnya dalam menyampaikan isu SARA yang baru marak di Indonesia. Pencermatan saat ini adalah, Indonesia menjadi negara yang terkuasasi oleh konflik horizontal, terjadi kondisi saling menghujat dan melemparkan kebencian di media sosial, perannya sederhana saja, lempar batu sembunyi tangan, sebagian besar orang tidak melihat dampak secara menyeluruh, yang dilihat adalah apakah emosi akan tersalurkan atau tidak. 
Dalam konteks Psikologi disebut dengan Konasi atau sebuah kemauan secara personal dan kelompok. Jika sudah berbicara kemauan, kita jelas merujuk kepada pribadi masing-masing. Sebab apa yang menjadi kemauan tiap individu berbeda dengan apa yang kita ingin sampaikan.

Kenyataan ini tidak dimaksudkan untuk membuat bingung. Namun, lebih dari itu sebagai sebuah upaya memahami bahwa memang ada banyak hal di luar diri kita dan tidak selayaknya menutup diri. Semakin terbuka seseorang, akan mengakibatkan semakin tingginya jati diri seseorang. Akibatnya, pandangan bahwa orang atau pihak lain lebih rendah, tidak cerdas akan semakin terkikis sedikit demi sedikit. Pandangan tertutup mengakibatkan individu "buta" tentang pluralisme, berpandangan sempit menurut diri dan kelompoknya, kepentingan dan mengklaim yang paling benar sendiri. Dalam kajian Komunikasi Lintas Budaya ini disebut dengan Etnosentrisme, atau menganggap budaya yang lain lebih rendah daripada budaya sendiri, secara Psikologi ini dinamakan dengan sifat superioritas, atau manusia superior, ingin menang sendiri.

Dalam propaganda selalu ada pihak yang dengan sengaja melakukan proses penyebaran pesan untuk mengubah sikap dan pandangan serta perilaku sasaran propaganda. Dalam propaganda individu yang melakukan ini disebut dengan propagandis. Propagandis bisa berupa individu, individu yang dilembagakan atau lembaga itu sendiri. Yang dimaksud orang yang dilembagakan adalah orang yang bergerak atas nama lembaga atau sebuah organisasi.

Propaganda dilakukan secara terus menerus, ini perlu digarisbawahi karena untuk membedakannya dengan kampanye. Jika propaganda dilakukan secara terus menerus sejauh kepentingan dari propagandis, namun di sisi lain kampanye dilakukan secara temporer, meskipun dalam kampanye bisa jadi digunakan teknik atau cara propaganda juga.

Ada proses penyampaian ide, gagasan, kepercayaan atau bahkan doktrin. Proses penyampaian pesan ini melibatkan cara tertentu, misalnya dengan melakukan Psikoterapi atau memberikan sugesti, agitasi [hasutan] dan rumor. Oleh karena itu, propaganda bagi pemahaman tertentu harus tertanam sifat objektivitas dan kejujuran, namun bagi yang lain, kebohongan, manipulasi juga dibenarkan. Propaganda juga mempunyai tujuan mengubah pendapat, sikap dan perilaku individu atau kelompok lain. Tujuan ini sedemikian pentingnya, sehingga muncul semacam sindiran bahwa apapun akan dilakukan propagandis untuk mewujudkan keinginannya tersebut.

Propaganda adalah sebuah seni usaha sadar. Dengan demikian, propaganda adalah sebuah cara sistematis, prosedural dan sudah melalui perencanaan matang. Perencanaan matang ini juga sudah melalui siapa sasaran dari propaganda tersebut. Caranya bagaimana? Lewat media apa dan seterusnya.

Propaganda juga sebagai sebuah program yang mempunyai tujuan kongkrit, maka propaganda akan mencapai sasarannya secara efektif jika menggunakan media yang tepat dan media yang sangat tepat untuk saat ini adalah media sosial.

\section{Pentingnya Moralitas}

Dalam mengakses media sosial, dibutuhkan sifat dan sikap yang disebut dengan integritas, individu yang melakukan ini disebut dengan integer. Pemahaman integer adalah

$104 \quad$ Fajar Dwi Putra 
orang yang jujur, lugu meskipun tidak naif atau polos, asli berdasarkan kekuatan kepribadian yang tidak memaksanya untuk terus menerus menyembunyikan wujud yang sebenarnya. Orang yang integer batinnya kuat, ia tidak dapat dibeli dan tidak pula korupsi. Ia orang yang mandiri, dalam arti bahwa ia bersedia mengambil sikap secara independen dari dan seperlunya melawan kelompok dan lingkungannya. (Nurudin; 2008; 115)

Jiwa esensi moral seharusnya juga dipunyai oleh seorang propagandis. Meskipun dalam banyak hal propaganda telah diselewengkan untuk kepenringn golongan tertentu, misalnya kepentingan suku, rass dan agama. Seseorang yang bermoral tentu saja tidak akan berbohong, jujur, terbuka dan sesuai dengan hati nurani dan tentu saja tidak ada unsur politis yang melatarbelakangi kepentingannya menyampaikan pendapat melalui media sosial. Untuk itulah, esensi itu harus dikembalikan ke posisi ideal. Layaknya sebuah komunikasi yang sekedar menyampaikan informasi kepada orang lain tanpa diselipi maksud terselubung.

Dengan moral, seorang propagandis akan mengarahkan dirinya untuk tidak jatuh ke lembah kenistaan diluar batas kemanusiaan. Dengan moralitas pula, usaha tidak jujur juga bisa ditepis. Seseorang yang tidak punya moralitas yang baik akan berusaha untuk berbuat bohong hanya untuk mengejar ambisi pribadi. Misalnya dengan mengatakan bahwa dirinya adalah kaum yang lemah, tak berdaya, pro-rakyat atau kata-kata yang bernada membela golongan tertentu demi mendapat dukungan.

Dalam konteks psikologi komunikasi, hal ini disebut dengan faking good atau berpura-pura baik dengan tujuan pencitraan. Sering kita melihat hujatan-hujatan bernada sara untuk memprotes sebuah kebijakan dibungkus dengan sorban agama tertentu. Menggiring persepsi masyarakat untuk ikut golongannya, sehingga persepsi itu dibentuk bahwa apa yang dikatakannya adalah benar, tentu saja kebenaran itu tidaklah hakiki, tapi dipaksa untuk menjadi hakiki dengan cara menyematkan dalil-dalil agama tertentu. Dan dalil itu pun tetap saja melamahkan agama tertentu.

Unsur akulturasi menjadi pilihan utama di sini, di mana golongan tertentu menganggap golongan lain tidak benar, dan hanya golongannya lah yang paling benar. Sikap ini yang terjadi dan sedang berlangsung di Indonesia, di mana warganya minim pengetahuan agama, moral dan esensi integritas dalam berkomunikasi, sehingga akan sangat mudah dipropaganda secara media sosial.

\section{Effek Psikologis}

Morisan (2010: 255) mengatakan efek merupakan perubahan-perubahan yang terjadi didalam diri individu akibat dari pesan-pesan media, namun yang diberi oleh media massa tidak pernah berorientasi pada kehendak pasar. Media hanya ingin memberikan sebuah informasi yang dianggap seolah-olah memang sebuah realitas. Ada lima jenis efek yang ditimbulkan oleh media massa (khususnya media sosial) secara Psikologis, diantaranya:

d. Efek Kognitif: Efek yang dapat mengubah nilai yang saat ini sudah ada dan terpelihara pada masyarakat. Efek ini terjadi bila ada perubahan pada apa yang diketahui, difahami atau dipersepsi khalayak. 
e. Efek Kognitif Media Massa: Komunikasi tidak langsung menimbulkan perilaku tertentu, tetapi cenderung mempengaruhi cara kita mengorganisir citra kita tentang lingkungan.

f. Efek Afektif: Efek ini merupakan proses yang berhubungan dengan emosi dan perasaan seseorang seperti ketakutan dan kegelisahaan. Efek ini timbul bila ada perubahan pada apa yang dirasakan, disenangi dan dibenci khalayak.

g. Efek Kultivasi: Efek ini memperkirakan dan menjelaskan pembentukan persepsi, pengertian dan kepercayaan mengenai dunia sebagai hasil dari mengkonsumsi pesan media dalam jangka waktu panjang.

h. Efek Behavioral Manusia: Efek ini merujuk pada perilaku nyata yang dapat diamati diantaranya pola tindakan, kegiatan atau berperilaku.

i. Apa saja yang sudah terjadi di media sosial kita secara perspektif Psikologis merujuk kepada sebuah pemahaman yang disebut dengan Agresi. Menurut Robert (2003: 47) Agresi adalah segala bentuk perilaku yang disengaja terhadap makhluk lain dengan tujuan untuk melukainya dan pihak yang dilukai tersebut berusaha untuk menghindarinya. Dari definisi tersebut terdapat empat masalah penting dalam Agresi. Pertama, Agresi merupakan perilaku. Kedua, ada unsur kesengajaan. Ketiga, sasarannya adalah makhluk hidup, terutama manusia. Keempat, ada usaha menghindar pada diri korban.

\section{Eufemisme}

Eufemisme merupakan acuan yang berupa ungkapan yang tidak menyinggung perasaan atau ungkapan halus untuk menggantikan acuan yang dirasakan menghina atau tidak menyenangkan. Intinya, mempergunakan kata-kata dengan arti baik. Eufemisme juga sering diartikan sebagai ungkapan yang bersifat tidak berterus terang.

Eufemisme atau juga Pseudo Eufemisme menjadi motif dorongan di belakang perkembangan peyorasi. Eufemisme berlatar belakang sikap manusiawi karena dia berusaha menghindar agar tidak menyakiti atau menyinggung perasaan orang lain. Seandainya tidak ada Eufemisme mungkin akan terjadi depresi makna atau perendahan makna. Namun di balik semua itu, Eufemisme ini dapat mengaburkan makna sehingga makna semula tidak terwakili lagi oleh bentuk atau konsep yang menggatikannya. Pergeseran makna ini tentu akan memberikan pengaruh terhadap masyarakat pemakai bahasa.

Tujuan awal yang baik Eufemisme ini adalah untuk bersopan santun. Namun, di balik semua itu ada hal-hal yang keluar dari tujuan semula tersebut. Kadang-kadang ada bagian Eufemisme yang penggunaanya sudah berlebihan sehingga apa yang ingin disampaikan tidak dapat tertangkap secara tepat oleh pembaca atau pendengar. Memang tujuan penggunaan Eufemisme tersebut adalah untuk bersopan santun tetapi ada juga yang bisa menipu. Oleh karena itu, dapat dikatakan bahwa Eufemisme adalah sopan santun yang menipu.

Hal itu tidak dapat dipungkiri karena banyak orang-orang tertentu yang pandai menggunakan bahasa dan berlindung di balik Eufemisme tersebut. Banyak pula di antara penggunanya merasa aman dengan pemanfaatan gaya bahasa seperti ini.

106 Fajar Dwi Putra 


\section{DAFTAR PUSTAKA}

Byrne, R. A. (2003). Psikologi Sosial "Edisi kesepuluh jilid 1". Jakarta: Penerbit Erlangga. Carole Wade, C. T. (2007). Psikologi "Edisi Kesembilan Jilid 2". Jakarta: Erlangga.

Devito, J. A. (1996). Komunikasi Antar Manusia. Jakarta : Profesional Books.

Dr. Muhammad Nur Islami, S. M. (2017). Terorisme "Sebuah Upaya Perlawanan". Yogyakarta: Pustaka Pelajar.

Fajar Junaedi, B. A. (2011). Mesin Pencuci Otak "Menggugat Tayangan Televisi Indonesia". Yogyakarta: Broadcasting Komunikasi UMY.

Greene, R. (2016). 33 Strategi Perang. Tangerang Selatan: Kharisma Publisher Group. Ismail. (2013). Ironi dan Sarkasme Bahasa Politik Media "Filsafat Analitik Jhon Langsaw Austin". Yogyakarta: Pustaka Pelajar.

Jamaludin, D. A. (2016). Dasar-Dasar Patologi Sosial. Bandung: Pustaka Setia.

Jess Feist, G. J. (2008). Theories Of Personality. Yogyakarta: Pustaka Pelajar.

Kansong, U. (2016). Jurnalisme Keberagaman Untuk Konsolidasi Demokrasi. Jakarta: MI Publishing.

Morissan, M. (2008). Media Penyiaran "Strategi Mengelola Radio dan Televisi. Jakarta : Kencana Publisher .

Morissan, M. (2010). Psikologi Komunikasi . Bogor: Ghalia Indonesia.

Olson, B. H. ( 2008). Theories Of Learning. Jakarta: Kencana.

Richards J. Heuer, J. (2016). Psikologi Intelijen. Yogyakarta: Prismashopie Publisher.

Taylor, K. (2010). Brainwhasing "Ilmu Tentang Pengendalian Pikiran". Yogyakarta: Aksara.

Tzu, S. (2016). The Art Of War "Menerapkan Seni Perang". Tangerang Selatan: Kharisma Publisher Group .

Zodir, Z. (2011). Mempercakapkan Relasi Agama \& Negara. Yogyakarta: Pustaka Pelajar Yogyakarta. 
